\title{
Factors Influencing Meat Consumption in Ijebu-North Local Government Area of Ogun States, Nigeria
}

\author{
Akinsulu A. A. ${ }^{1} \quad$ Ajijola S. $^{2^{*}} \quad$ Odetola S.K. $^{3} \quad$ D.O. Awoyemi ${ }^{2}$ \\ 1.Department of Agricultural science Education, Tai Solarin University of education, Ijagun, Ijebu- Ode, Ogun \\ state, Nigeria \\ 2.Institute of Agricultural Research and Training, Moor Plantation, Ibadan \\ 3.Department of Agricultural Economics, University of Ibadan, Nigeria
}

\begin{abstract}
This study examines the factors influencing meat consumption in Ijebu North local government area of Ogun state. This area was chosen because it has the best ultra modern abattoirs in Ogun state. Simple random sampling was used to gather data from one hundred (100) respondents with the aid of structured questionnaire. Demographic characteristics of the respondents showed that those whose age ranges between 30-40years consume more meat than the rest age groups; majority of the respondents $(52 \%)$ has secondary education. The average monthly household income of the respondents is $\mathrm{N} 65,979.80$, majority of them (54\%) preferred beef to other type of available sources of meat in the study area. Multiple regression result revealed that the age and income of the consumers were significant at 1\% while household size and educational level of the consumers were significant at $5 \%$. Gender and marital status have positive relationship to meat consumption. It was recommended that government should make sure that there is constant electricity for adequate storage which will make meat available at all times, also there is need for promotion of means of employment generation to the youths for income generation that will enable them to purchase enough meat to supply adequate protein. Also, consumer should form cooperative society so that they can purchase cattle and sell at cheaper price for members.
\end{abstract} Keywords: Household, Consumption, Meat, Preference, Ogun state DOI: $10.7176 / \mathrm{JMCR} / 52-03$

\section{INTRODUCTION}

The supply of animal protein in Nigeria is unevenly distributed throughout the country and sometimes within the households, where urban dwellers eat more animal protein than those living in rural areas because urban dwellers earn higher income which enables them to afford the market price. Poverty is a major factor that limit the amount of meat consumed by household throughout the country, the rural population is especially prone to malnutrition as majority of them are poor where most people consume the minimum level of calorie but fail to get the necessary proteins, essential vitamins and minerals required for healthy living. (Sanusi and Adewoyin, 2014).

The level of meat consumption has direct influence on general wellbeing, health and productivity of the people. Protein of animal origin is not just preferred because of its palatability but because it is essential for normal physical and mental development of man. In Nigeria, it has been reported that animal protein contributes only $8.6 \%$ of an estimated $51.7 \%$ daily protein intake of the average Nigerian. The recommended total minimum intake for an adult is $85.9 \%$ per day of which about $34 \mathrm{~g}-40 \mathrm{~g}$ should be from animal origin. However, a shortfall of $16.4 \%$ protein intake of animal origin in the diet of an average Nigerian has been reported by (Abdulrahman, et al, 2013).

The meats from cattle, goat, sheep, pig and poultry, are the main sources of animal protein consumed in Nigeria, where it was estimated that the daily minimum crude protein requirement of an adult in Nigeria varies between $65 \mathrm{~g}$ and $85 \mathrm{~g}$ per person, and it was recommended that $35 \mathrm{~g}$ of this should be obtained from animal products. Consumer preference explains how a consumer ranks a collection of goods or services or prefers one collection over another. This definition assumes that consumers rank goods or services by the amount of satisfaction, or utility afforded. This shows that a preference of choice for consumption exists in spite of the importance of meat as a source of protein with high biological value. Factors that affect the consumption of meat can be classified as economic, social and cultural factors, specifically, religion, age, sex, socio-economic factors, individual variation and income are major factors that have influenced meat consumption pattern in Nigeria. Sanusi and Adewoyin, (2014) opined that some of those factors that influence preference for meat include nutritional value, taste, freshness or tenderness, availability, affordability, ease of preparation or cooking, fat content and several others.

Meat consumption pattern and consumer preference have been studied by many authors. Gamba et al (2013) examined the influence of income, meat price, gender, age on meat consumption, it observed that prices, income, taste and preferences are the key variables affecting meat consumption level. Abdulrahman et al (2013) stated that there are different kinds of meat depending on the source from which they are obtained, for example mutton is obtained from sheep, chevron from goat, beef from cattle and pork from pig. Meat is nutritious and 
highly attractive in appearance and therefore cherished by most people in the world. The main reason for consuming meat is to derive protein from it, protein is importance for the wellbeing of man. Proteins are important because they are the only dietary source of amino acids that are obtained from both plant and animals sources, and that proteins from animal sources are preferred to that of plants because protein from the animal sources are generally high and also contain the essential amino acids in a balanced ratio needed by the body. The human body cannot produce these essential amino acids which are needed in the proper ratio for many biological processes; hence animal protein is able to provide these essential amino acids.

Ademosun (2012) reported that, even though the exact livestock population in Nigeria is not known, whatever the figures may be, the average Nigerian eats less meat than the average European, and American. The demand for protein of animal origin is higher in the cities than the villages this is believed to be so for a number of factors. He attributed this to the high cost of animal products such as meat, milk and eggs which is beyond the reach of an average rural dweller. He also noted that, the wide gap between demand for animal protein by those living in the urban areas and that of the rural group is due to differences in income, level of education and availability of protein. Meat consumption varies worldwide, depending on culture or religious preferences, as well as economic conditions. Many people choose not to eat a particular meat because of ethical, economical, environmental, religious or health concern that are associated with the type of meat (Robert and Nwaiwu, 2010).

Despite the important of meat to health, its average consumption per head in most Africa countries is very low with about $25 \mathrm{~g}$ below the recommended $200 \mathrm{~g}$ per day (FAO, 2000). Also as important as meat is, the estimated average consumption per person in Nigeria in 2010 was about 9.6kilogrammes consumed per person compare to those in the middle east and other parts of Africa (Anaro, 2011). Household demand for meat products such as beef, mutton, pork, chevon and chicken are faced with problems which is mostly due to market prices, consumers taste wealth or income which in most cases leads to unbalanced diet and consequently poor nutritional status resulting in weakness, lethargy, poor productivity and stress (Jamison, 2001). In spite of the vast natural resources at its disposal, Nigeria remains among the least animal protein consumer in Africa (Uamai, 2000).

Statistics show that Nigeria's per-capita meat consumption is approximately 6.4 kilogrammes per annum, China's is about 23 kilogrammes, but, Canadians consume an average of 65 kilogrammes a year and the citizens of the US eat 95 kilogrammes. Nigeria is not only one of the largest meat producing countries in Africa but also one of the largest meat consumers in this region of the world, according to a study titled 'Consumerism: Statistical Estimation of Nigeria Meat Demand' by (Osho and Asghar 2011).

Considering all these factors, this study was carried out with the objectives to, Examine different type of meat consumers preferred most in the study area, Examine those factors that determine meat consumption, Constraints faced by the respondents in meeting their meat consumption expectation, and examine the household expenditure on meat in the study area.

\section{Theoretical Review}

Consumer behaviour is the study of how, when and why people buy what they buy. It attempts to explain the buyer decision - making process both individually and in groups. The theory of consumer behaviour assumes that a consumer is rational and aims at attaining the highest possible satisfaction given his income and the prevailing market prices. He attempts spending his income in a way that gives him maximum satisfaction. An individual's decision on what range and type of food to consume is influenced greatly by income and other factors such as social norms. According to Engel law, the income elasticity on food consumption is low since with increasing income, people's spending on food decreases and a large percentage of additional income is committed to luxuries. The life - style of people in urban cities is different from that of their counterparts in rural areas and this also influences to a considerable extent, their food consumption patterns. Most urban low income house - holds in Nigeria are plagued with inadequate animal protein intake due to lack of money to buy them

Ekine, et al (2012) analyze the expenditure patterns and determinant of beef consumption in selected households in Southern Nigeria. Specifically, the study was designed to estimate the monthly expenditure on beef; evaluate the influence of household income and household size of expenditure on beef as well as determine the consumption of beef by households in the study area. Structured questionnaire was used to elicit information from sixty households using the simple random sampling technique. It was observed that income is the major determinants of household expenditure on beef. Yakaka and Bashir (2012) analyzed the determinants of ruminant meat demand in Maiduguri town using 150 randomly selected households, the study was taken between the period of May-June, 2011. The finding revealed that gender, age and educational level of household heads were insignificant determinant of expenditure on ruminant. On the contrary, household size and income had positive coefficients and are significant at $1 \%$ level.

Adetunji and Rauf (2012) investigated household demand for meat in some selected states in the Southwest Nigeria. The systematic sampling technique was used to select two hundred and forty household in the study area and data were collected through well structured questionnaire. Analysis was done using Descriptive 
Statistics and Almost Ideal Demand System (AIDS) Model. The findings showed that the budget share of beef decreased with an increase in the price of chicken and vice versa, but increased with an increase in its price, the budget share of chevon, chicken and mutton increased with an increase in their own prices respectively. Mutton and pork were confirmed to be luxury goods while chicken, beef and chevon were normal goods for households in southwest, Nigeria.

Anzaku, et al (2013) focused on the types of meat preferred by consumers and the attributes which influence the consumption of meat. Where 200 consumers were randomly selected from Shabu, Akurba, Gayam, Zanuwa and Chiroma wards of Lafia Local Government Area where varieties of meat are consumed. Analysis of data was achieved using descriptive statistics and cluster analysis. Results showed that cattle, goat, sheep, chicken, turkey, rabbit, duck, pig, dog, goose, cat and rat meat were consumed. Views of individual consumers in the three clusters determined - quality, demographic and handling attributes, indicated high degree of influence on choice of meat. From the results, awareness has been created on preferences of different types of meat and the basis for the segmentation of meat market has been established.

\section{RESEACH METHODOLOGY}

STUDY AREA: This study was carried out in Ijebu North local government area of Ogun State in South Western Nigeria. It has land area of $967 \mathrm{Km} 2$ and a population of 284,336 at 2006 census. The local government was created in 1979 and has headquarter at ijebu igbo It was bounded by Oluyole local government area of Oyo state in the North, in the west by ijebu east, In the South by Ijebu North East, Odogbolu and Ijebu ode local government and in the east by Ikenne Local Government. . It lies at a coordinate of $6^{\circ} 57^{\prime} \mathrm{N} 4^{\circ} 00^{\prime} \mathrm{E} 6.95^{\circ} \mathrm{N} 4^{\circ} \mathrm{E}$. The major occupation of the People in the area is farming coupled with pretty trading, milling, plank selling, cow meat selling etc. Ijebu Igbo, the local government headquarter is well reputed for cow meat selling as the town has one of the best ultra modern abattoirs in Ogun state.

\section{SAMPLING PROCEDURE AND ANALYTICAL TECHNIQUE}

Primary data was collected with the aid of structured questionnaire which was administered to the household head. Multi-stage sampling technique was used to elicit data from the respondents. First stage was the purposive selection of the local government known to be reputed for cow meat selling and the area with the best ultra modern abattoirs. Second stage was the purposive selection of five communities due to their activities in cow meat selling. Third stage was the random selection of twenty households from the selected communities. This gives the sample frame of 100 households.

Descriptive statistics was used to describe the socio-economic characteristics of the respondents and multiple regression was used to determine those factors that affect household meat consumption in the study area.

The regression equation is stated as: $\mathrm{C}=\mathrm{b}_{0}+\mathrm{bi}$

$\mathrm{C}=\mathrm{b}_{0}+\mathrm{b}_{1} \mathrm{x}_{1}+\mathrm{b}_{2} \mathrm{x}_{2}+\mathrm{b}_{3} \mathrm{x}_{3}+\mathrm{b}_{4} \mathrm{x}_{4}+\mathrm{b}_{5} \mathrm{x}_{5}+\mathrm{b}_{6} \mathrm{x}_{6}+\mathrm{b}_{7} \mathrm{x}_{7}+\mathrm{b}_{8} \mathrm{x}_{8}+\mathrm{U} 1$

Where;

$\mathrm{C}=$ Total amount spend on meat consumption monthly.

$\mathrm{X}_{1}=$ Household size of respondent (number)

$\mathrm{X}_{2}=$ Income of household $(\mathrm{N})$

$\mathrm{X}_{3}=$ Level of education (years)

$\mathrm{X}_{4}=$ Marital status (married $=0$, single $=1$ )

$\mathrm{X}_{5}=$ age of respondents (years)

$\mathrm{X} 6=$ Taste $($ dummy yes $=1$, no $=0)$

$\mathrm{X} 7=\operatorname{Sex}($ dummy male $=1$, female $=0)$

$\mathrm{X} 8=$ Cost price $/ \mathrm{kg}(\mathrm{N})$

$\mathrm{U}=$ Error term (These are factors that cannot be accounted for in the model).

\section{Result and discussion}

Table 1: The socio-economic characteristics of the respondents.

Table 1 shows that the age of the respondents that fall between the ages between $15-30 \mathrm{yrs}$ are $28 \%, 20 \%$ fall between the ages $31-40 \mathrm{yrs}, 34 \%$ are between the age of $41-50 \mathrm{yrs}, 10 \%$ fall between the age of 51-60yrs, while $8 \%$ fall between the age of 60 and above, with mean age of 48.36, this implied that most of the respondents are youths in their active age that can work for high income to consume meat. Majority $(58 \%)$ of the respondents have household between $4-6$ members. $34 \%$ of the respondents have a household size between $1-3$, and $8 \%$ have a household size between 7 -- 9. The mean household size in the study area was 5. This number may lead to increase in the quantity of meat consumed by the households.

The educational attainment of the respondents in the area showed that $38 \%$ of them are educated up to tertiary level. Those with primary and secondary education are $6 \%$ and $52 \%$ respectively, while $4 \%$ has no formal education, this is an indication that there is high level of formal education in the study area which could 
lead to increase in the amount of meat consumed since it is believed that education increase the awareness of consumers on the nutritive value of meat in human diet, and also enhance employment of jobless people (Osho and Asghar 2011). The marital status showed that 34\% of them were single and $60 \%$ were married, $2 \%$ and $4 \%$ are divorced and widow respectively. The occupation of the respondents showed that $30 \%$ engage in trading, $12 \%$ engage in artisan, $10 \%$ engage in farming, $42 \%$ and $6 \%$ are civil servant and other jobs respectively, this shows that all groups of people in the study area consume meat. $14 \%$ of the respondents earn below $\$ 30,000$, $30 \%$ earned between N30,000-N60,000, majority representing 40\% earned between N61,000-N90,000, 6\% earned between N91,000 -- N120,000 and 10\% earned above N120,000, While the average monthly income is $\mathrm{N} 65,979.8$, this shows that most household head in the study area earned between N61,000 -- N900,000 per annum.

\section{Table 2 Type of meat and Preferences of the Consumers}

Table 2 shows that $54 \%, 8 \%, 38 \%$, and $10 \%$ of the respondents preferred beef, chicken, pork, and goat respectively. This is an evidence that majority of those living in the study area prefer beef than other type of meat, the reason they gave among other things include that beef is less expensive than other type of meat, the quantity of beef is higher than that of chicken and beef is readily available in every towns and villages, also there is no religious taboo against it. Also $32 \%$ of the respondents like meat for it taste, $30 \%$ of them consume meat for its flavour while $4 \%$ of the respondents like meat for its colour, and $34 \%$ preferred the type of meat as a result of nutritive awareness study area, this could be as a result of high number of literate residents in the area.

Majority of the respondents $(72 \%)$ are of the opinion that meat readily is available throughout the year in the study area, $20 \%$ of the respondents respond that meat is fairly available and $8 \%$ of the respondents respond that meat is not available, this means that meat is readily available in the study area, this could be due to large abattoir in Ijebu-Igbo town which is the headquarter of the local government areas (Table 3 ).

Table 3 also shows that, $86 \%$ of the respondent have the awareness of importance of meat to human health, while $14 \%$ of the respondents don't know the importance of meat to health, this means that most of those that consume meat in the study area have the awareness of importance of meat, this could be due to high number of educated people in the area.

The constraint, that limit the respondents from consuming as much meat as required was ranked based on the frequency of their responses. Low income of consumer is the highest with frequency of $62 \%$, High level of poverty $48 \%$, Increase in meat price $42 \%$, Household size $36 \%$, Religious $24 \%$, Level of education $20 \%$, and Poor storage facility $16 \%$ (Table 4 ).

\section{Table 5: Regression result showing the factors that influenced the level of meat consumption.}

Those factors that were modelled to determine meat consumption pattern of consumers in the study area are household sizes, income of consumer, level of education, marital status, age, sex, taste, and cost of meat per kilogram. The Multiple regression result showed that the household size, income level of the household, education and age of the respondents are positively and have statistically significant influence on the amount of meat consumed by the respondents, this showed that as these variable are increasing amount of meat consume will also increase. The household size and education of the consumers are statistically significant at $5 \%$ level, as the household size increases the quantity of meat consumed also increases, consequently, the amount of money spent monthly increases, the reason may be that the amount of meat consumed by each household is directly proportional to the size of the house hold since every member of the household is expected to consume meat. Income of consumer also tended to increase the household expenditure on meat significantly at $1 \%$ level.

This could be that as the amount of income of household increases their purchasing power which make them to afford to buy more meat also increases. The statistical significance of education could be explained on the ground that educations make the consumers to have knowledge of nutritive importance of meat in the diet. The age of household was also found to positively affect household expenditure on meat; this relationship was significant at $1 \%$ level indicating that meat consumption increases as the age of the household head increases. The reason could be in line with average age 48.36years of the respondents who are mostly at their active age, since the young ones require meat and are energetic to work for good pay that will enhance increase in their income. The adjusted $\mathrm{R}^{2}$ of $61 \%$ is an indication that variation in the amount of money spent monthly on meat are explain by the independent variables while the remaining $39 \%$ is due to error term, $\mathrm{F}$ value $=8.235$ is significant showed that socio-economic variables jointly determine the amount of meat consumed by the households and Durbin-Watson $=2.224$ showed that there is no evidence of autocorrelation in the model.

\section{Conclusion and Recommendation}

Result from the study revealed that household size, income of consumer, level of education etc. affect their level of meat consumption. People between the age of 30-40years consume more meat than the rest age group, because they are in their active age hence, have enough money to purchase meat, the mean family size is 4.06. The result also indicated that $52 \%$ of the consumers who has secondary education consume more meat than the primary and tertiary educated peoples. The average monthly income of the respondents is $\mathrm{N} 65,979.80$, majority 
of them (44\%) preferred beef to other type of available sources of meat in the study area. There is significant relationship between the quantity of meat consumed by the respondents and age of the consumers, household size and income of the consumers and household size.

Based on the outcome of the study, it is recommended that: Government should make provisions for adequate storage facilities which will make meat available at all times regardless of the season. This could be done by making sure that there is good electricity power supply, also there is need for promotion of means of employment generation by the government so that youths can have a mean of income generation this will enable them purchase enough meat to supply adequate protein, Consumer should form cooperative society so that they can contribute money together that will enable them to purchase cattle in large number from the northern part of the country and slaughter for sale at cheaper rate for members. If all these and other factors are adequately considered it is expected to facilitate increase in the meat consumption of consumers leading to protein sufficiency.

\section{REFERENCES}

Abdulrahman, A. M. Mufwa, B. J. Musa, B. \& Innocent, S. B. (2013). Pattern of meat consumption in Jalingo Local Government Area in Northern Taraba State, Nigeria. Journal of agriculture and veterinary sciences, 5(2): $95-104$.

Ademosum, A. (2012). The Livestock Sub - section in the Third National Development Plan. Nigeria Journal of Animal Production, 3(1): $10-17$.

Adetunji, M. O. \& Rauf, M. O. (2012)). Analysis of housedholds demand for meat in Soutwest, Nigeria. Global journal of science frontier research agriculture and biology, 12(1): $14-22$.

Anzaku, T. A. Anda, S. A. \& Agwale, A. O. (2013).Preferences for the types of meat consumed in Lafia Government Area of Nasarawa State, Nigeria. PAT Journal, 9(1): 91 - 97.

Ekine, D. I. Albert, C. O. \& Peregba, T. A. (2012). Expenditure pattern for beef consumption in selected households in Southern Nigeria. Developing country studies, 2(7): $1-5$.

Gamba, P. Kariuki, D. \& Gathigi, B. (2005). Urban domestic consumption patterns for meat; Trends and policy implications. Tegemo Institute of Agricultural Policy and Development, Egerton University

Osho G. S. and Asghar Nazemzadeh (2011). Meat consumption and our health. Business day Friday, 04 November 2011. Statistical Estimation of Nigeria Meat Demand' by, University of Houston-Downtown

Robert, U. \& Nwaiwu, J. (2012). Micro - level analysis of beef and fish consumption in Imo state, Nigeria. Agricultural research and review 1(1), $1-8$.

Sanusi, W. A. \& Adewoyin, J. A. (2014). Analysis of consumer preference for meat types in Ogbomoso metropolis of Oyo State, Nigerian. Journal of Agriculture economics and rural development, 2(1): $16-20$.

Yakaka, B. M. \& Bashir, A. B. (2012). Determinants of ruminants meat demand in Maiduguri, Borno State, Nigeria, Greener journal of Agricultural sciences, 2(8): $381-385$. 
Table 1 Socio-economic characteristics of the respondents.

\begin{tabular}{|c|c|c|}
\hline Variables & Frequency & percentage $(\%)$ \\
\hline \multicolumn{3}{|l|}{ Age (Years) } \\
\hline $15-30$ & 28 & 28 \\
\hline $31-40$ & 20 & 20 \\
\hline $41-50$ & 34 & 34 \\
\hline $51-60$ & 10 & 10 \\
\hline Above 60 & 08 & 08 \\
\hline \multicolumn{3}{|l|}{ Mean $=48.36$} \\
\hline \multicolumn{3}{|l|}{ Household Size } \\
\hline $1-3$ & 34 & 34 \\
\hline $4-6$ & 58 & 58 \\
\hline $7-9$ & 08 & 08 \\
\hline \multicolumn{3}{|l|}{ Mean $=5.6$} \\
\hline \multicolumn{3}{|c|}{ Educational attainment (Years). } \\
\hline No education & 04 & 04 \\
\hline Primary education & 06 & 06 \\
\hline Secondary education & 52 & 52 \\
\hline Tertiary education & 38 & 38 \\
\hline \multicolumn{3}{|l|}{ Marital Status } \\
\hline Single & 34 & 34 \\
\hline Married & 60 & 60 \\
\hline Divorced & 02 & 02 \\
\hline Widowed & 04 & 04 \\
\hline \multicolumn{3}{|l|}{ Occupation } \\
\hline Traders & 30 & 30 \\
\hline Artisan & 12 & 12 \\
\hline Civil servants & 22 & 22 \\
\hline Farmers & 30 & 30 \\
\hline Native doctor & 06 & 06 \\
\hline Total & 100 & 100 \\
\hline \multicolumn{3}{|l|}{ Monthly income (N) } \\
\hline Below 30,000 & 14 & 14 \\
\hline $30,000-60,000$ & 30 & 30 \\
\hline $61,000-90,000$ & 40 & 40 \\
\hline $91,000-120,000$ & 06 & 06 \\
\hline Above 120,000 & 10 & 10 \\
\hline Total & 100 & 100 \\
\hline Mean $=\mathrm{N} 65,979.8$ & & \\
\hline
\end{tabular}

Source: Field survey 2014

Table 2: Type of meat consumed and Preferences by household in the study area

\begin{tabular}{ll}
\hline Type of meat consumed & Percentage (\%) \\
\hline Beef & 54 \\
Chicken & 38 \\
Pork & 08 \\
Goat & 10 \\
Preferences & Percentage (\%) \\
Taste & 32 \\
Flavour & 30 \\
Colour & 04 \\
Nutritional Satisfaction & 34 \\
\hline
\end{tabular}

Source: Field survey 2014 
Table 3: Availability of meat consumed and Awareness by household

VARIABLE PERCENTAGE (\%)

Availability

72

Fairly available

20

Not available

20

Total

100

Awareness

Yes

86

No

14

Total

100

Source: Field survey 2014

Table 4: Constraints faced by the respondents in meeting their meat consumption expectation.

\begin{tabular}{lll}
\hline Constraint & Ranking & Percentage (\%) \\
\hline Low income of consumer & 1 & 62 \\
High level of poverty & 2 & 48 \\
High selling price & 3 & 42 \\
Household size & 4 & 36 \\
Religious & 5 & 24 \\
Level of education & 6 & 20 \\
Poor storage facility & 7 & 16 \\
\hline
\end{tabular}

Source: Field survey 2014

Table 5: Factors influencing level of meat consumed by the farming household

\begin{tabular}{|l|c|c|l|}
\hline Variables & $\mathrm{B}$ & Std Error & $\mathrm{T}$ \\
\hline (Constant) & -10035.730 & 6589.593 & -1.523 \\
H.size & 286.161 & 117.153 & $2.443^{* *}$ \\
Income & 0.035 & .013 & $2.666^{* * *}$ \\
Education & 269.744 & 156.378 & $1.725^{* *}$ \\
Marital & 464.326 & 328.873 & 1.412 \\
Age & 56.342 & 14.887 & $3.785^{* * *}$ \\
Cost price & -355.611 & 277.972 & -1.279 \\
Flavour & 2550.094 & 1620.170 & 1.574 \\
Sex & 1752.810 & 1642.814 & 1.067 \\
\hline
\end{tabular}

$\mathrm{R}^{2}=0.712$

Adjusted $\mathrm{R}^{2}=0.607$

$\mathrm{F}$ value $=8.235^{* * *}$

*** Significant at 0.01

** Significant at 0.05

Durbin-Watson $=2.224$

* Significant at 0.10

Source: Field survey 2014 